\title{
Coral diseases on Philippine reefs: genus Porites is a dominant host
}

\author{
Laurie J. Raymundo ${ }^{1,2, *}$, Kathryn B. Rosell ${ }^{2}$, Clarissa T. Reboton ${ }^{2}$, Longin Kaczmarsky ${ }^{3}$ \\ ${ }^{1}$ Marine Laboratory, University of Guam, UOG Station, Mangilao 96923, Guam \\ ${ }^{2}$ Silliman University Marine Laboratory, Dumaguete City 6200, Philippines \\ ${ }^{3}$ Long Island University, Brookville, New York 11548, USA
}

\begin{abstract}
While it is generally assumed that Indo-Pacific reefs are not widely affected by diseases, limited data suggest a number of diseases and syndromes that appear to differ from those currently under study in the Caribbean. This report presents the results of a baseline survey of coral diseases in 2 regions in the Philippines: the Central Visayas and the Lingayen Gulf. Mean prevalence for all diseases observed was $8.3 \pm 1.2 \%$ (mean $\pm \mathrm{SE}_{\mathrm{i}} \mathrm{n}=8$ reefs), with Central Visayas reefs showing higher disease prevalence $(11.6 \pm 2.8 \% ; \mathrm{n}=4$ reefs $)$ than those of Lingayen Gulf $(5.1 \pm 1.4 \% ; \mathrm{n}=4$ reefs $)$. Five diseases and syndromes were described; 3 of these-Porites ulcerative white spot disease (PUWS) (prevalence $=8.96 \pm 2.2 \%$ ), tumors (prevalence $=1.0 \pm 0.5 \%$ ) and pigmentation response (prevalence $=0.5 \pm 0.2 \%$ ) - occurred frequently in both regions and targeted the genus Porites. Correlation between disease prevalence and number of Porites colonies was fairly strong $\left(\mathrm{r}^{2}=43.4\right)$, though not significant, and no correlation was seen between prevalence and either the amount or diversity of hard coral. Porites is a major reef-builder in the Indo-Pacific comprising $30 \%$ of hard coral colonies on our surveyed reefs, and is generally thought to be a hardy, long-lived genus. Diseases targeting this robust group present an as yet unquantified risk to Philippine reefs and could result in major changes in reef structure.
\end{abstract}

KEY WORDS: Coral disease $\cdot$ Philippines $\cdot$ Porites $\cdot$ Disease prevalence $\cdot$ Host range $\cdot$ Species diversity

\section{INTRODUCTION}

Reef scientists today must protect and manage coral reefs that continue to be subjected to a variety of assaults including over-harvesting, destructive fishing, eutrophication and siltation. Marine diseases have recently been added to this list of impacts. Concern is growing regarding the effects of infectious diseases on reef community structure as a number of studies have suggested that impacts can be considerable. Aronson \& Precht (1997) and Aronson et al. (1998) demonstrated that recent changes in reef structure brought about by white band disease are unprecedented for the past 3800 yr. The well-documented epizootic that killed the major herbivore Diadema antillarum provided compelling evidence of the structuring force that a disease can impose, par- ticularly when combined with anthropogenic stressors such as overfishing (Hughes 1994). Data suggest that the number of diseases affecting marine species is increasing via both host and range shifts (Harvell et al. 1999, Ward \& Lafferty 2004). Climate change is predicted by some to increase host susceptibility and host range, pathogen survival and disease transmission (Ritchie et al. 2001, Harvell et al. 2002), while others predict fewer impacts with density-dependent modes of transmission as host populations decline (Lafferty \& Holt 2003). Clearly, the effects of environmental factors are complex and synergistic and as yet are poorly understood.

The Western Atlantic is considered a hotspot for coral reef diseases. Few reefs within this region remain unaffected (Richardson 1998, Bruckner 2002). Consequently, this region has been the focus of disease- 
related research and much of our current understanding of disease etiology, causal agents and impacts to reef communities comes from research on these reef systems. However, outbreaks are not limited to the Caribbean (Antonius 1985, 1988, Alder \& Braley 1988, Coles 1994, Littler \& Littler 1996) and the increase in diseases may be a world-wide phenomenon that is unquantified and under-reported. In addition, while both Black Band and White Band diseases have a circumglobal distribution, host species show much variation between oceans (Gladfelter 1982, Antonius 1985, 1988, Coles 1994). However, most diseases appear to have a more limited geographic range. Aspergillosis is widely dispersed throughout the Caribbean (Nagelkerken et al. 1997) but has not been reported elsewhere. Porites ulcerative white spot disease (PUWS) affects reefs in the Philippines and possibly elsewhere in the Indo-Pacific (Raymundo et al. 2003), but has not been described in Caribbean poritids. However, the signs of PUWS are similar to another syndrome ('white spot syndrome') reported in the Caribbean affecting massive corals (Global Coral Reef Alliance web page; cited in Bruckner 2002). These observations raise numerous questions that can guide future research. How do host range and disease etiology differ between oceans? Which diseases reported from widely dispersed geographical regions are caused by the same pathogen? How do differences in reef diversity and human impacts affect the severity of disease outbreaks?

The coral reefs of the Indo-Pacific are the most diverse in the world. A total of 581 species of scleractinian corals have been reported from this region. In contrast, the Western Atlantic has 62 reported species (Veron 2000). This diversity could be predicted to lower the spread of infectious diseases that are limited in host range as the probability of pathogens encountering a host would be reduced in a highdiversity community. Alternatively, more diverse reefs could harbor a greater diversity of pathogens. IndoPacific reefs show the highest global diversity in most taxonomic groups (Spalding et al. 2001), although microbial community diversity has not been documented. Information regarding diseases in the Indo-Pacific region is very limited and little quantitative work has been accomplished. Antonius (1985) reported the first survey of Philippine reefs, finding 20 species in 8 families with white band infections and 2 species with both white band and black band diseases. No other diseases were described in this first survey. Several syndromes and anomalies from the region have been described qualitatively (see Bruckner 2002 and Sutherland et al. 2004 for summaries) and species exhibiting these disease signs have been identified. However, the majority of these reports describe single point-in-time observations and should serve only as a starting point for a more in-depth investigation.

A few diseases have been documented quantitatively. Preliminary work on a new disease, PUWS, quantified its host range, prevalence, incidence and seasonality in the central Philippines (Raymundo et al. 2003). Pink line syndrome (here referred to as pigmentation response) is widespread throughout the Indo-Pacific and thought to be caused by the cyanobacterium Phormidium valderianum (Ravindran \& Raghukumar 2002), but the pathogen has not yet been isolated from diseased tissues, nor has it satisfied Koch's postulates. A transfection study carried out in laboratory aquaria suggested that the condition is not infectious (Azcuna 2005). Two bacterial pathogens (Vibrio shiloi, Kushmaro et al. 1998; and V. coralliilyticus, Ben-Haim et al. 2003) have been found to cause bleaching in the corals Oculina patagonica and Pocillopora damicornis, respectively. Finally, skeletal eroding band affects a number of coral genera in Papua New Guinea, Australia, the Red Sea and the Indian Ocean, and has been found to be caused by the boring activities of the ciliate Halofolliculina corallasia (Antonius \& Lipscomb 2000).

This paper reports the results of a recent baseline survey to identify diseases affecting hermatypic corals in the Philippines. Philippine reefs are among the most impacted in the world, with an estimated $98 \%$ of these reefs suggested to be at medium to high risk from threats ranging from destructive fishing to eutrophication (Burke et al. 2002). Two regions differing in geographic position within the archipelago were selected for preliminary rapid assessment surveys (Fig. 1). The Lingayen Gulf is a large bay on the western margin of Luzon Island that opens to the South China Sea. In contrast, the Central Visayas region is in the central part of the country, which has local water circulation within the semi-enclosed Mindanao Sea and was the site for the original surveys by Antonius (1985). Both regions experience intense fishing pressure, which can include illegal methods such as dynamite and cyanide. Erosion, agricultural runoff and eutrophication from sewage also impact local areas in both regions (Udarbe-Walker \& Magdaong 2003, authors' pers. obs.). Marine protected areas (MPAs) have been established within each region. These provided sampling sites for what was considered the best coral cover/reef health in the area. The objectives of this survey were to quantify diseases that were previously recorded within the country, to develop a species list of hosts affected by each disease observed and to describe any apparently 'new' syndromes or potential diseases. This baseline information will be used for future in-depth studies targeting specific diseases or syndromes, to 
elucidate pathogens, disease progression and impacts to the reef community.

\section{MATERIALS AND METHODS}

Prior to surveys, reefs were selected in each region that represented contrasting states of disturbance: relatively undisturbed vs. impacted by human activity. 'Relatively undisturbed' is defined here as a reef actively and continually protected from harvesting (i.e. MPAs), high hard coral cover relative to dead coral/rubble, with clear water and no obvious nearby sources of nutrient or silt input. At each site, both shallow and deep transects were laid at approximately equal distances apart (distance between transects was estimated using the same number of fin kicks between each transect; shallow transects ranged from 2 to $4 \mathrm{~m}$; deep transects ranged from 5 to $10 \mathrm{~m}$ ), except for the Agan-an and Looc sites. These 2 sites represent different sections of an extensive fringing reef along Dumaguete City, Negros Island. The reef is very shallow and 2 sampling depths were not possible, so 2 different sections were sampled to maintain the same replication as on other reefs. At each depth, three $2 \times 20 \mathrm{~m}$ belt transects were laid. All diseased colonies within this belt were noted and the number of diseased vs. healthy colonies per species was counted so that disease prevalence could be calculated. In spite of the very high diversity of most reefs, this was possible largely because Porites appeared to be the only genus that was regularly observed to be affected by disease. Therefore, we concentrated our efforts to quantify healthy vs. diseased colonies on this genus alone. In addition, the total number of Porites colonies (diseased and healthy) and the total number of hard coral colonies were counted for a $2 \times 10 \mathrm{~m}$ segment of each transect, to calculate the percent contribution of the genus Porites to the hard coral community at each site and to determine overall prevalence. Our initial efforts focused on diseases previously documented from the country: black and white band diseases and PUWS. In addition, pigmentation response and skeletal anomalies, hereafter referred to as tumors, were also observed. We define a tumor as 'an abnormal tissue proliferation', as described in Sutherland et al. (2004), which in corals also involves the underlying skeleton. This appears to be the most appropriate term to apply for the distinctive gross colony surface irregularities we regularly observed on massive Porites. Aside from these diseases, new signs of disease, either biotic or abiotic in origin, were described and photographed when encountered and the species displaying them were identified.

Two other types of data were collected within these belt transects. The Line-Intercept method was used to
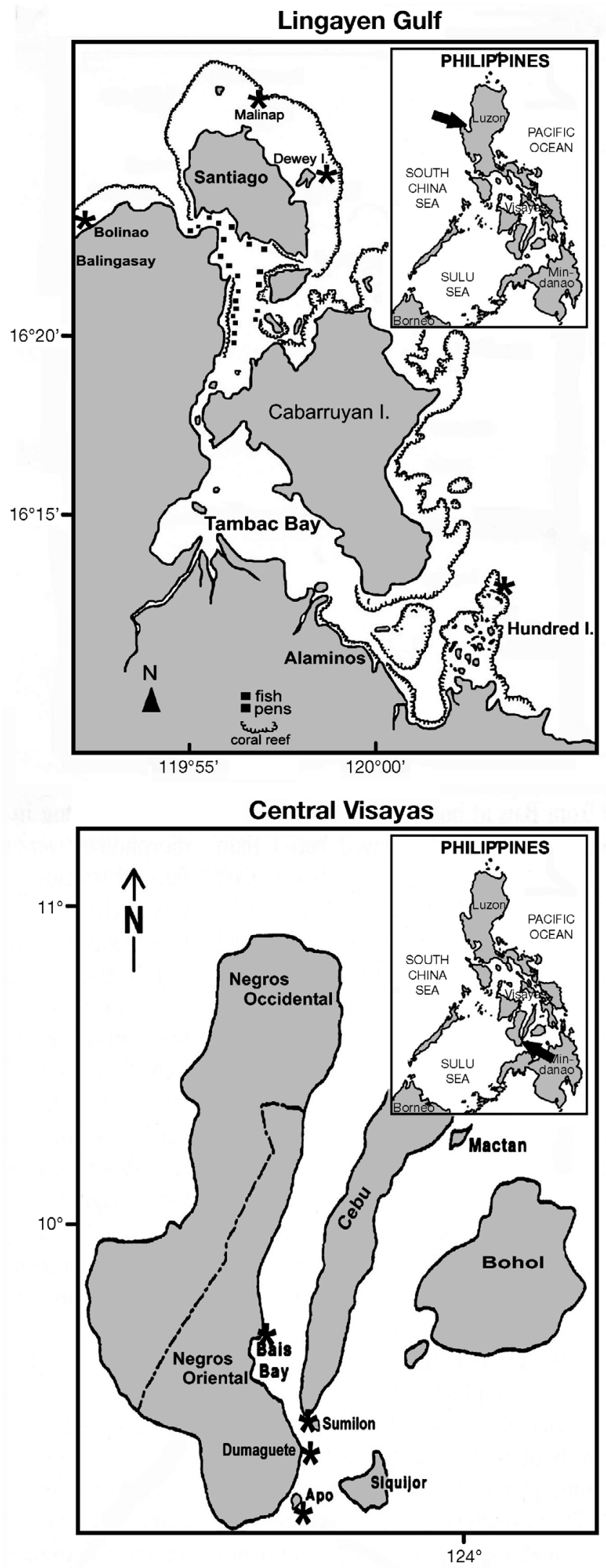

Fig. 1. Map of the Philippines showing the respective study sites. *: individual reefs surveyed 
obtain a detailed description of substrate composition and the following substrate categories were noted: live hard coral, soft coral, recently killed hard coral, weathered rock with turf algae, rubble, sand, silt, canopyforming algae and other encrusting organisms (such as sponges, ascidians, gorgonians). Additional information on poaching, pollution sources and other human stressors was obtained by interviewing local fishers and managers. Hard coral diversity was obtained along five $2 \mathrm{~m}$ segments bisecting each transect at $5 \mathrm{~m}$ intervals. Species were identified in situ where possible, or small pieces were collected for identification in the laboratory when necessary. Identification of specimens was based on Veron (2000) and Wallace (1999). Species diversity was determined using Simpson's index of concentration by combining species lists for all transects within a reef. Simpson's index is useful for such sampling as it does not depend on sample size or require a specific type of abundance distribution (Rosenzweig 1995). In order to determine if the number of segments we sampled per reef $(n=30)$ was a sufficient representation of diversity, we counted the number of new species added per segment. In all reefs, the number of new species approached zero prior to the thirtieth segment, so we assumed that our sample number was adequate.

Disease prevalence was calculated as follows (see explanation above):

$$
\frac{\text { number of diseased colonies per transect }}{\text { total number of colonies per transect }} \times 100
$$

This was computed per depth and per reef for all diseases, and per species per reef for PUWS. To examine a possible connection between disease prevalence and Porites host abundance, the relative abundance of each species was calculated per reef as the total number of colonies per Porites species/total number of all colonies and this also allowed a calculation of Porites spp. abundance relative to all other species. A 2-way ANOVA was used to detect differences in prevalence between the 2 regions (Lingayen Gulf and Central Visayas) and the 2 depths surveyed (shallow and deep). Regression analysis was used to examine connections between disease prevalence and live hard coral cover, hard coral diversity and Porites spp. abundance.

\section{RESULTS}

A summary of the survey sites is presented in Table 1. Most sites in both regions had reduced water quality from sewage, silt and runoff, and were heavily fished. Information regarding the use of cyanide was obtained from interviews with local fishers. The Lingayen Gulf (LG) reefs, in particular, were stressed from continual nutrient input and particulate material from numerous fish cages that lined the coast. Balingasay Marine Reserve was the only reef unaffected by these fish cages, as it was located around the northern point of the gulf, facing the South China Sea (Fig. 1). In the Central Visayas (CV), North Bais Bay showed the

Table 1. Site descriptions of reefs surveyed for disease. LHC = live hard coral; RU = rubble; DC = dead coral. Percent substrate composition values are mean \pm SE. Simpson's index values close to 0 signify higher diversity and those approaching 1 signify lower diversity

\begin{tabular}{|c|c|c|c|c|c|}
\hline \multirow{2}{*}{$\begin{array}{l}\text { Survey } \\
\text { site }\end{array}$} & \multirow{2}{*}{$\begin{array}{l}\text { Simpson's } \\
\text { index }\end{array}$} & \multicolumn{3}{|c|}{ Percent substrate composition } & \multirow[t]{2}{*}{ Possible stressors } \\
\hline & & LHC & RU & $\mathrm{DC}$ & \\
\hline \multicolumn{6}{|l|}{ Central Visayas } \\
\hline Apo Is. ${ }^{a}$ & 0.179 & $37.90 \pm 16.4$ & $3.13 \pm 1.9$ & $2.30 \pm 0.5$ & $\begin{array}{l}\text { Tourist-diving coral } \\
\text { breakage (minimal) }\end{array}$ \\
\hline North Bais Bay & 0.022 & $37.55 \pm 10.4$ & $28.85 \pm 8.8$ & $14.0 \pm 4.1$ & $\begin{array}{l}\text { Agricultural runoff, } \\
\text { cyanide, silt, overfishing }\end{array}$ \\
\hline Agan-an/Looc & 0.074 & $45.13 \pm 6.74$ & $2.88 \pm 2.9$ & $11.83 \pm 4.4$ & $\begin{array}{l}\text { Sewage, overfishing, } \\
\text { cyanide fishing, silt }\end{array}$ \\
\hline Sumilon Is. ${ }^{a}$ & 0.125 & $31.26 \pm 7.4$ & $5.48 \pm 4.6$ & $2.09 \pm 2.1$ & $\begin{array}{l}\text { Anchor damage, tourist } \\
\text { diving, poaching }\end{array}$ \\
\hline \multicolumn{6}{|l|}{ Lingayen Gulf } \\
\hline Balingasay $^{\mathrm{a}}$ & 0.067 & $31.88 \pm 7.38$ & $2.92 \pm 1.5$ & $3.17 \pm 1.1$ & Seasonal heavy waves \\
\hline Malilnep & 0.151 & $33.71 \pm 3.8$ & $9.17 \pm 4.8$ & $20.83 \pm 6.5$ & $\begin{array}{l}\text { Silt, overfishing, sewage, } \\
\text { cyanide }\end{array}$ \\
\hline Victory, Dewey Is. ${ }^{a}$ & 0.033 & $38.13 \pm 9.7$ & $6.29 \pm 1.9$ & $6.33 \pm 3.8$ & $\begin{array}{l}\text { Silt, overfishing, sewage, } \\
\text { cyanide }\end{array}$ \\
\hline Governor Is. & 0.069 & $42.42 \pm 4.1$ & $11.29 \pm 4.3$ & $9.67 \pm 2.0$ & $\begin{array}{l}\text { Dynamite fishing, silt, } \\
\text { cyanide, overfishing }\end{array}$ \\
\hline
\end{tabular}


highest hard coral diversity and high live hard coral cover, but also high rubble and dead coral values. This reef receives agricultural and river runoff and is known to contain large amounts of fertilizers, pesticides, effluent from a sugar processing plant and silt. Both the best-managed marine reserves, Apo Island (CV) and Balingasay (LG), had high water quality, with lower coral diversity and the lowest values for dead coral and rubble. Although our original intention was to select an equal number of sites that varied distinctly in water quality and overall reef health (i.e. healthy vs. impacted or degraded reefs), Apo Island and Balingasay appeared to be the only sites that truly fit the description of reefs with minimal impacts from human activities. The other marine reserves, Sumilon Is. (CV) and Victory (LG), showed a very depauperate and sparse fish population, suggesting some poaching in spite of protection. Victory, in particular, was extremely silty, but as it was a shallow, lagoonal platform reef with a high percentage of apparently healthy faviids and other massives, we suspected that the reef had developed under somewhat silty conditions. The pre-existing silty condition has recently been greatly exacerbated, however, from the nearby fish cages.

We identified a number of diseases and syndromes present on our surveyed reefs; these are described in Table 2. Fig. 2 presents photographs of each disease. Mean total disease prevalence for all diseases observed on all reefs was $8.28 \pm 1.16 \%$ (mean $\pm \mathrm{SE}$ ). Our surveys revealed no confirmed infections of either white band or black band diseases previously recorded by Antonius (1985). PUWS, tumors and pigmentation response were the most commonly observed conditions and affected the genus Porites almost exclusively.

The present survey expanded the previously recorded host range of PUWS (Raymundo et al. 2003). A total of 10 branching Porites species were infected with PUWS (Table 2) compared with the 6 species previously listed as susceptible. The massive species $P$. lobata, $P$. lutea, $P$. australiensis, $P$. solida, and $P$. mayeri were identified in the laboratory from our transects,
Table 2. Description of diseases and syndromes affecting corals in the Philippines

\begin{tabular}{|c|c|c|}
\hline Disease/Syndrome & Gross description & Host species \\
\hline $\begin{array}{l}\text { Porites ulcerative } \\
\text { white spot disease } \\
\text { (PUWS) }\end{array}$ & $\begin{array}{l}\text { Small ( } 3 \text { to } 5 \mathrm{~mm} \text { ) white } \\
\text { lesions found either singly } \\
\text { or in small clusters. Lesions } \\
\text { may contain bleached tissue } \\
\text { which either progresses } \\
\text { to tissue necrosis and death, } \\
\text { or polyp recovery. Advanced } \\
\text { infections involve lesion } \\
\text { coalescence and spreading; } \\
\text { dead skeleton is colonized by } \\
\text { algae. Colony death can occur } \\
\text { within } 1 \text { yr. Commonly found }\end{array}$ & $\begin{array}{l}\text { Massive Porites } \\
\text { P. cylindrica, } \\
\text { P. attenuata, } \\
\text { P. nigrescens, } \\
\text { P. tuberculosa, } \\
\text { P. horizontallata, } \\
\text { P. annae, P. latistella } \\
\text { P. lichen, P. rus, } \\
\text { P. sillimaniana, } \\
\text { Goniastrea minuta, } \\
\text { Favia stelligera }\end{array}$ \\
\hline Tumors & $\begin{array}{l}\text { Irregular patches of skeleton } \\
\text { either raised or depressed } \\
\text { relative to surrounding healthy } \\
\text { tissue. Surface texture distinct } \\
\text { from healthy tissue, with distinct } \\
\text { margin between the two. Tumor } \\
\text { tissue discolored. Microscopic } \\
\text { examination showed deformed } \\
\text { corallites and skeletal irregu- } \\
\text { larities. Fairly commonly found }\end{array}$ & Massive Porites \\
\hline $\begin{array}{l}\text { Pigmentation } \\
\text { response }\end{array}$ & $\begin{array}{l}\text { Found along margins of dead or } \\
\text { necrotic tissue, colonized by turf } \\
\text { algae. Margins highly pigmented } \\
\text { with pink, blue or yellow band } \\
2 \text { to } 4 \mathrm{~mm} \text { wide produced by host } \\
\text { colony. Pink exuded material may } \\
\text { accumulate along the innermost } \\
\text { lesion/dead skeleton border, } \\
\text { accompanied by thickening of } \\
\text { walls of affected corallites. Fairly } \\
\text { commonly found }\end{array}$ & Massive Porites \\
\hline Necrotic syndrome & $\begin{array}{l}\text { Irregular patches of necrotic } \\
\text { tissue with mucous discharge. } \\
\text { Within the patch, the tissue is } \\
\text { bleached and discolored. Patches } \\
\text { bordered by } 2 \text { mm chalky, white } \\
\text { band. Patches found near colony } \\
\text { margin, around crevice in colony, } \\
\text { or facing an infected neighboring } \\
\text { colony. Commonly found on } 1 \text { reef }\end{array}$ & Massive Porites \\
\hline White syndrome & $\begin{array}{l}\text { White band of exposed skeleton } \\
\text { from recently killed tissue. Tissue } \\
\text { death appears to begin in center of } \\
\text { foliose colony, spreading toward } \\
\text { margin; older exposed skeleton } \\
\text { is algae-colonized. Rarely found }\end{array}$ & Montipora informis \\
\hline
\end{tabular}

but we were unable to verify in situ which of these species were infected, due to difficulties with both field identification and sampling. In addition, 2 faviid species (Goniastrea minuta and Favia stelligera) were observed to exhibit PUWS-like lesions on 2 different reefs (one in each region), suggesting that host range is not limited to the genus Porites. Mean prevalence of 

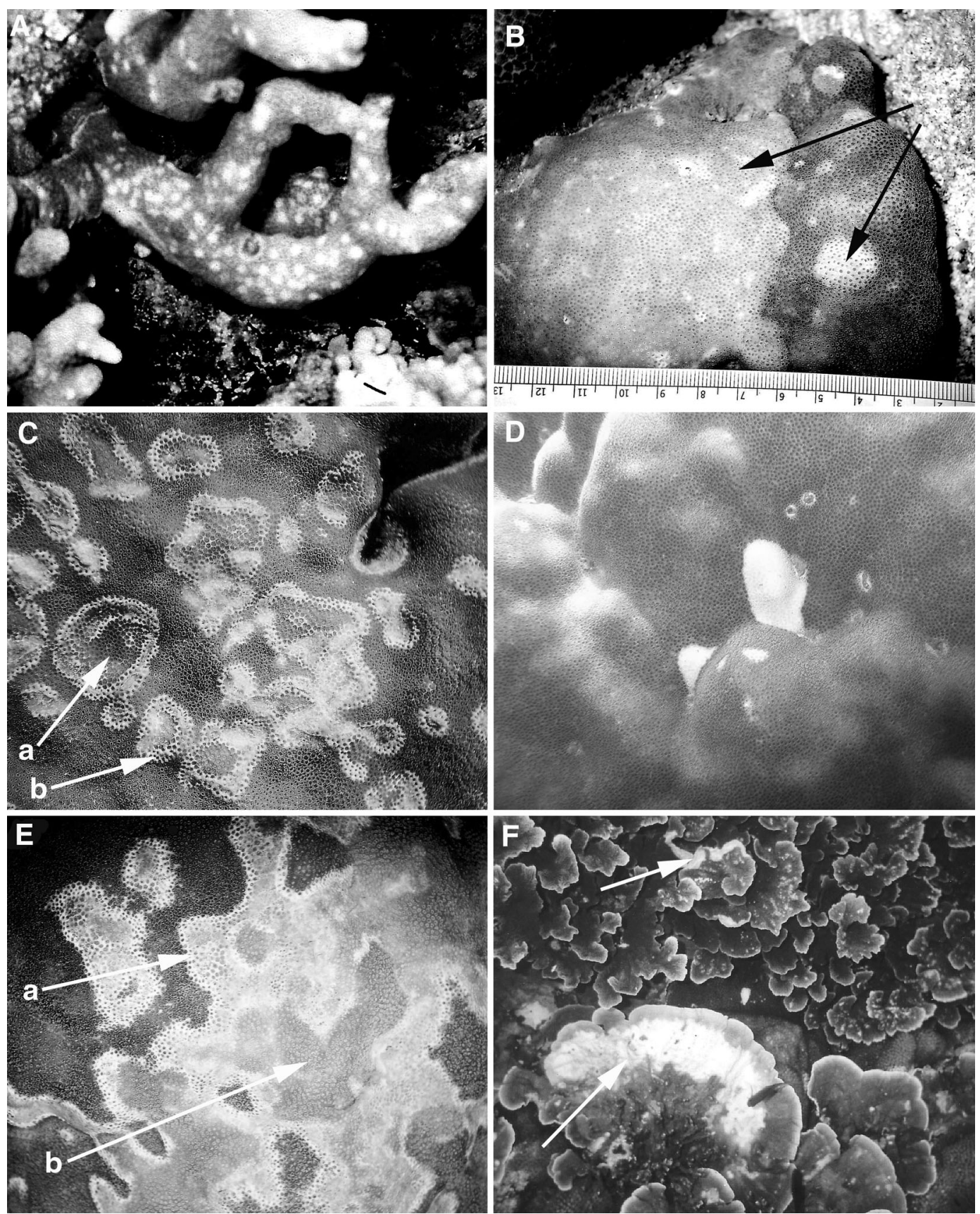

Fig. 2. Diseases affecting Philippine corals. (A) Porites ulcerative white spot disease on Porites attenuata. (B) Tumors; arrows at affected portions of massive Porites colony. (C) Pigmentation response on massive Porites; (a) arrow pointing to highly pigmented tissue, (b) arrow pointing to increased skeletalization around affected corallites. (D) White blotch on massive Porites. (E) Necrotic syndrome on massive Porites; (a) arrow pointing to white, chalky band, (b) arrow pointing to necrotic tissue. (F) White syndrome; arrows pointing to 2 affected patches on Montipora informis. Photo credits: L. Raymundo, L. Kaczmarsky

PUWS within the genus Porites on surveyed reefs was $8.96 \pm 2.2 \%$.

Tumors were found in both regions, possibly affecting all massive Porites species we encountered, and mean prevalence within the genus on all reefs was $1.01 \pm 0.5 \%$. Colonies affected by both PUWS and tumors were occasionally observed. Pigmentation response is an ill-defined condition, commonly seen in massive Porites and possibly associated with the cyanobacterium Phormidium valderianum (referred to as pink line syndrome by Ravindran \& Raghukumar 2002). It is characterized by irregular patches of dead 
skeleton on massive Porites, bordered by a highly pigmented margin. Such margins may also border cavities created by certain boring organisms and competitors. Pigmentation response has been described as a generalized stress response of the host coral to what appears to be many varied agents, and therefore would be considered an example of an abiotic disease. The response may vary in intensity and color; we regularly observed margins of pink, blue and yellow on different colonies. However, a distinctive feature of this response is the production (apparently from the coral itself) of a bright pink material along a lesion border that may be accompanied by increased skeletalization of affected corallites, which causes a visible thickening of corallite walls (Fig. 2). Although few colonies per reef manifested these patches, we observed it regularly on reefs in both regions (mean prevalence within the genus on all reefs was $0.5 \pm 0.2 \%$ ). The prevalence of these 3 diseases is presented in Fig. 3.

On a single reef in LG, we observed yet another condition affecting massive Porites. 'Necrotic Syndrome' was observed on Governor Is. (Table 2) affecting $25.3 \%$ of the large massive Porites (large massives comprised approximately $38 \%$ of total live coral cover on this reef). Extensive necrotic patches occurred along colony margins, crevices in the colony surface or on colony surfaces facing a similar patch on a neighboring colony. These patches were characterized by discoloration and abundant mucous production, and the presence of a chalky, white material in a band between healthy and diseased tissue (Fig. 2). A similar condition was subsequently observed on 3 colonies in the Agan-an reef the following year.

A suite of disease signs consistent with those of white syndrome reported from the Great Barrier Reef (Willis et al. 2004) affected colonies of Montipora informis at the Apo site (Fig. 2). This syndrome was not quantified, as the reef portion where it was observed was outside our transected area, but colonies displaying disease signs have been observed on several different occasions. Therefore, we mention it in this report.

Between-reef differences in prevalence were significant (ANOVA; $F=10.777, \mathrm{p}<0.0001$ ). Dumaguete and Sumilon Is. showed much higher prevalence than all other reefs; the 2 best protected marine reserves, Balingasay and Apo Is. showed very little disease (Fig. 4A,B). Prevalence was significantly lower on LG reefs $(5.09 \pm 1.4 \%)$, than on $\mathrm{CV}$ reefs $(11.6 \pm 2.79 \%$; ANOVA $; F=9.139, \mathrm{p}=0.0041, \mathrm{df}=1)$. There was no
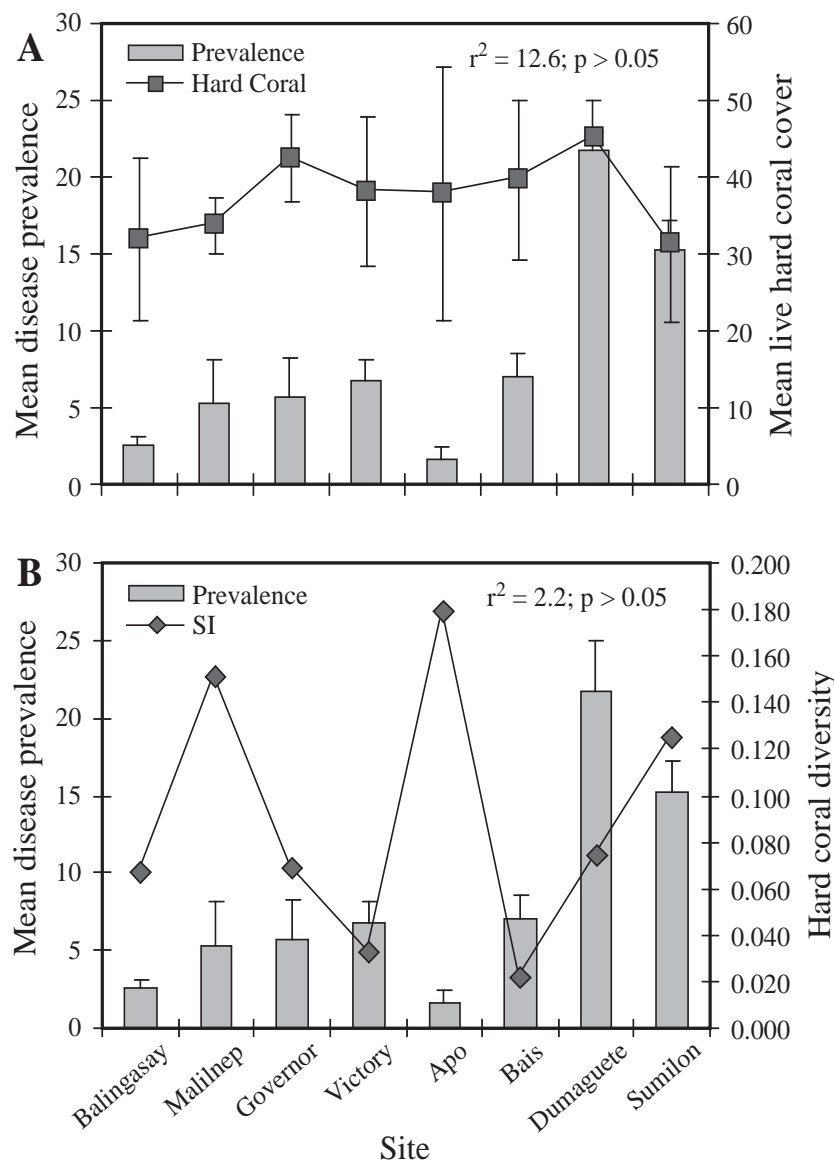

Fig. 4. (A) Mean total disease prevalence vs. mean hard coral cover per reef. (B) Mean total disease prevalence vs. total hard coral diversity per reef. ( $N=8$ reefs, 2 depths per reef; $\mathrm{n}=3$ transects per depth; mean $\pm \mathrm{SE}$ ). Simpson's index of concentration provides a value between 0 and 1 ; the lower values signify higher diversity 


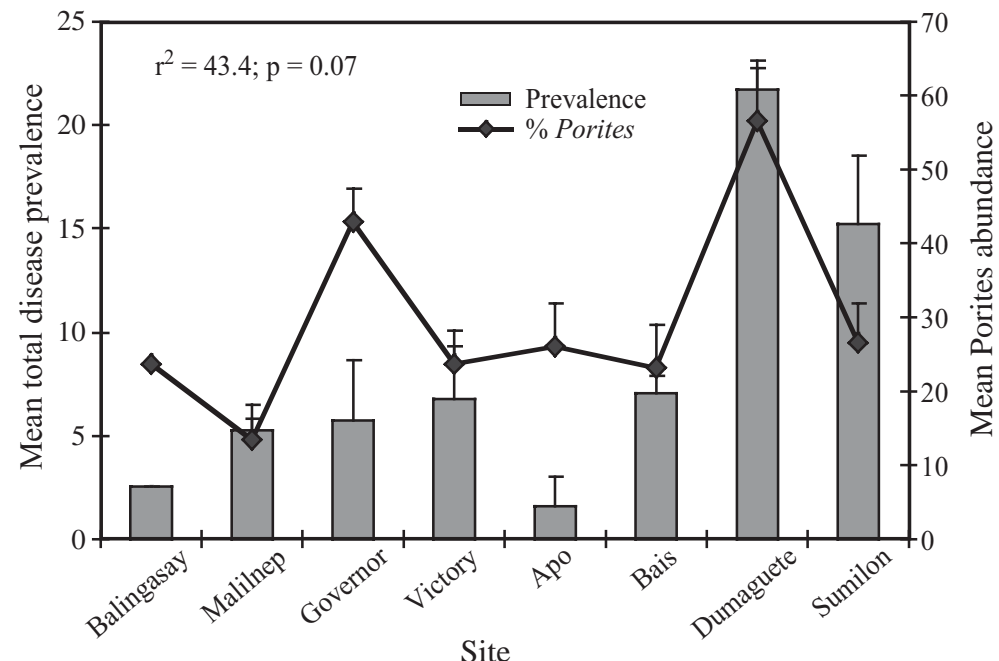

Fig. 5. Disease prevalence and Porites spp. abundance per reef. Prevalence calculated per reef as the number of diseased colonies per species/total number of colonies per species $\times 100$; relative abundance calculated per reef as the total number of colonies per species/total number of Porites spp. colonies $\times 100 . N=8$ reefs; Mean $+\mathrm{SE}$

difference in prevalence between shallow and deep transects (ANOVA; $F=2.157, \mathrm{p}>0.05)$. It was not possible to do a statistical analysis of prevalence between 'good' and 'impacted' reefs as we had too few reefs that we considered to be relatively healthy.

The genus Porites was particularly vulnerable to all diseases we observed; indeed, 'white syndrome' was the only disease noted that did not affect the genus and only rarely was any other genus observed to be diseased. Porites is a major contributor to reef structure on most reefs, comprising a mean of $29.9 \pm 3.2 \%$ (range $=$
4.3 to $68.5 \%$ ) of the total hard coral colonies along our transects. As expected, given the apparent susceptibility of Porites to the observed diseases, there was a fairly strong positive correlation between disease prevalence and the abundance of Porites colonies per reef (Fig. $5 ; r^{2}=43.4, p=0.076$ ). Though data suggested a weak relationship between the amount of live coral cover and disease prevalence (Fig. 4A), this relationship was not statistically significant $\left(\mathrm{r}^{2}=12.6, \mathrm{p}=\right.$ 0.389 ). No relationship between total disease prevalence and hard coral diversity was suggested (Fig. 4B; $\mathrm{r}^{2}=2.2, \mathrm{p}=0.727$ ). Prevalence of PUWS among species of Porites present on our transects was highly variable, and not strongly correlated with species abundance (Fig. $6 ; \mathrm{r}^{2}=14.7, \mathrm{p}>0.05$ ). However, we observed that the rarer species were almost never infected, while the 2 most common Porites, P. cylindrica and the massive Porites (australiensis, lutea, and lobata), did not show the highest disease prevalence. $P$. deformis and P. sillimaniani, while relatively uncommon, showed the highest prevalence for PUWS.

\section{DISCUSSION}

Our preliminary surveys have provided baseline information on the status of coral disease affecting reefs in the Philippines, a country within the global center of coral reef biodiversity. Our data represent one of the first attempts to quantify disease impacts in

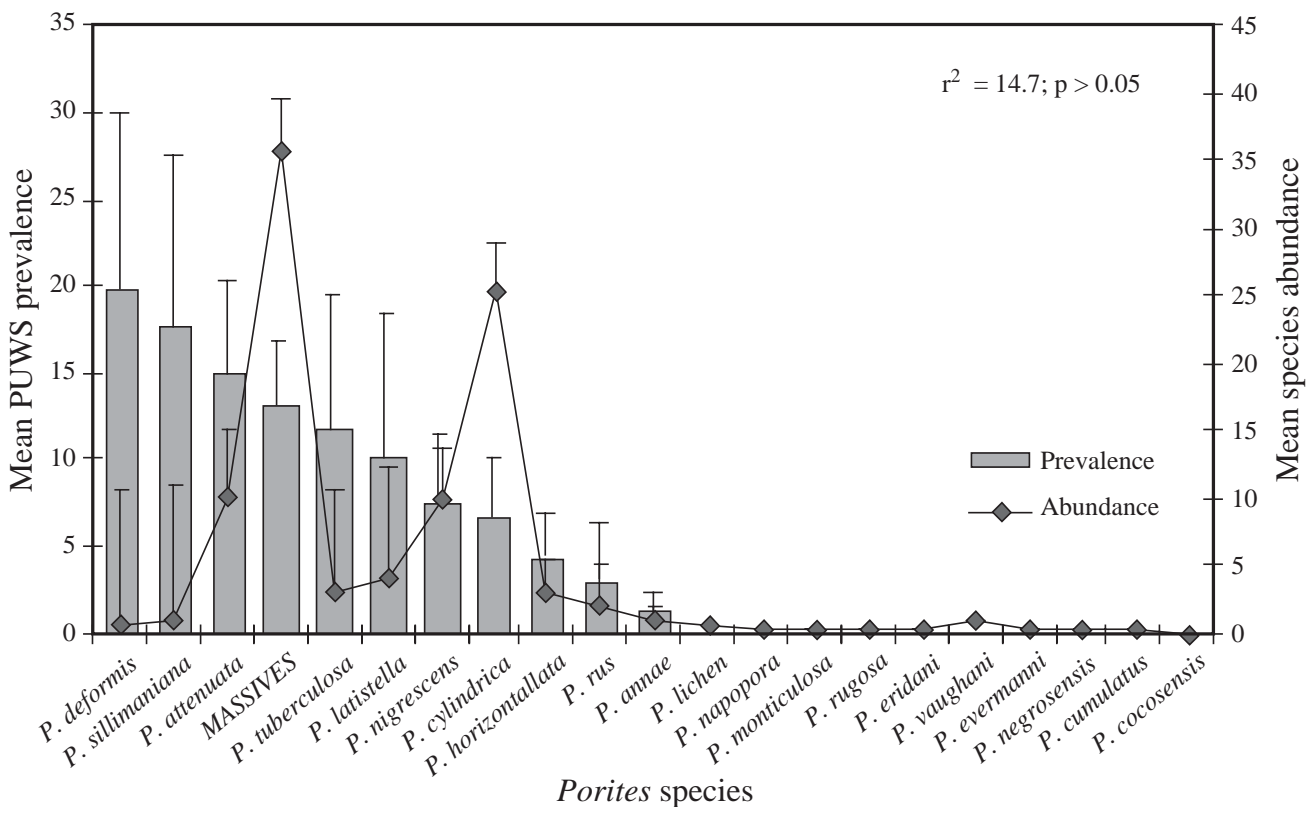

Fig. 6. Total disease prevalence and relative colony abundance for Porites spp. Prevalence calculated per reef as the number of diseased Porites colonies/total number of Porites $\times 100$; relative abundance calculated as the total number of Porites colonies/total number of colonies $\times 100$. $\mathrm{N}=$ 8 reefs; mean $+\mathrm{SE}$ 
the Indo-Pacific. Our results verified the presence of one described disease, PUWS, outside the previously recorded range of the Central Visayas region and increased the host range of this disease from the previous report (Raymundo et al. 2003). Our surveys also suggested the presence of a number of other potential diseases: namely, tumors and white blotch, which have not been previously recorded or adequately described. White syndrome and pigmentation response have been reported elsewhere in the region and represent the first records from the Philippines.

Our results were comparable with previous work on PUWS prevalence in Central Visayas reefs (Raymundo et al. 2003). Surveys in 1998 and 1999 also showed highest prevalence in Sumilon and Bais, with no infected colonies in Apo and Agan-an. Mean PUWS prevalence in 1998 was $22 \%(\mathrm{n}=8$ reefs in the Central Visayas; Raymundo et al. 2003), as opposed to our current value of $9 \%(\mathrm{n}=8$ reefs in Central Visayas and Lingayen Gulf). However, past surveys were accomplished during the 1997-98 El Niño bleaching event, which may have contributed to the higher prevalence. Four years later, Apo Is. is still relatively unimpacted by disease. Differences in PUWS prevalence among the branching species of Porites suggests differences in susceptibility between species as prevalence was not strongly correlated with species abundance. Rarer species were almost never infected as would be predicted with an infectious disease. However, the 2 most abundant groups, massive Porites (australiensis, lutea and lobata) and Porites cylindrica, did not show the greatest PUWS prevalence. Prevalence was greatest among 2 relatively rare species, $P$. deformis and $P$. sillimaniani, though between-site variability was very high. This suggests that certain species may be more susceptible to the disease than others.

Although one of our objectives was to examine the effect of reef health on disease prevalence, the rarity of truly healthy reefs within our sampling regions made it impossible to conduct such a comparison. A largerscale survey is needed to elucidate relationships between disease prevalence and reef health, water quality, hard coral cover and hard coral diversity. Another related question is the relationship between disease prevalence and the pattern of water circulation or flushing to which a particular reef is exposed. One theory put forth to explain high disease prevalence among Caribbean reefs is that the entire region is structured as a single large basin within which water locally circulates, affected by deposited African dust (Garrison et al. 2003). Thus, there appears to be a low correlation between reef health and disease outbreaks and apparently healthy reefs show high prevalence of disease (Goreau et al. 1998, Jordan-Dahlgren et al. 2005). The Philippines, being an archipelago with internal local circulation patterns but bounded by the South China Sea and Pacific Ocean, provide a uniquely appropriate location for studying disease prevalence on reefs affected by local circulation vs. reefs which are continually or seasonally flushed by open ocean water. Our preliminary surveys, including the semi-enclosed reefs of the Central Visayas which are influenced by local circulation, and the more exposed and seasonally flushed reefs of Lingayen Gulf that drain into the South China Sea, suggested such an influence. Sea surface temperatures were similar for both regions in April 2003, averaging 27 to $29^{\circ} \mathrm{C}$, but they had risen to 30 to $32^{\circ} \mathrm{C}$ by May in the Central Visayas, during our surveys (SEAWiFs images: http://oceancolor.gsfc.nasa.gov). Lingayen Gulf temperatures were not available for May, but they were generally cooler $\left(29\right.$ to $31^{\circ} \mathrm{C}$ ) along the outer margins of the country. Furthermore, all but one (Balingasay) of the Lingayen Gulf survey sites were heavily impacted by silt, agricultural runoff, eutrophication, blast fishing and overfishing, and yet consistently showed lower disease prevalence $(5 \%)$ than did Central Visayas reefs $(11 \%)$, which generally had higher water quality and were less impacted by human activity.

Both tumors and pigmentation response were seen in massive Porites within a broad range of size classes, but we could not determine the exact host range of each of these without sampling each colony underwater for later identification. 'pink line syndrome' (Ravindran \& Raghukumar 2002) is actually a misnomer. We observed several different types of hyperpigmentation along the margins of variably sized dead patches of massive Porites, possibly reflecting pigmentation differences in the host coral. In addition, microscopic examination clearly revealed that the line is composed of coral skeleton, produced by the host coral; it is not a microbial band as is seen in the band diseases. It is widely assumed to be a generalized response to a diverse array of stressors, but the absence of such a response around predation scars, tumor patches and PUWS lesions suggests that not all damage to the colony surface results in such a response. It seems reasonable to speculate that unidentified chemical and/or microbial agent(s) may trigger this response or secondarily infect compromised tissue. Harvell (pers. comm.) suggests that such margins may represent a hypermelanization response to a pathogen, similar to what is observed in diseased gorgonian sea fans infected with Aspergillosis (Petes et al. 2003).

Threats to biodiversity are considered one of the major predicted impacts of new diseases and those infecting multiple species (Kim et al. 2003). We expected a relationship between diversity and disease prevalence, as high prevalence of a disease with multiple hosts can 
lower diversity (Kuta \& Richardson 2002). In contrast, a high-diversity reef could be predicted to be more resistant to an infectious disease, if host species are less abundant. However, we found only a very weak relationship between the two $\left(r^{2}=2.2, p>0.05\right)$, possibly because of our small sample size. Our diversity calculations did not vary widely between sites (Table 1, Fig. 4B), and the reef with the lowest diversity, Apo Is., had the healthiest reef community and highest water quality. Although water quality has historically been very high (i.e. no eutrophication, silt, agricultural runoff, etc.), the marine reserve at Apo is dominated by large colonies of the massive coral Galaxea fascicularis, which suffered high mortality during the $1998 \mathrm{El}$ Niño bleaching event. Recovery of this species has been slow (Raymundo \& Maypa 2003), and soft corals have colonized much of the open substrate. This accounts for the low diversity of hard corals, though Porites spp. are major components of the reef flat community and would be predicted to show disease signs if pathogens were present.

Porites is generally considered a hardy, slow-growing, robust genus. It survives well when transplanted (Clark \& Edwards 1995), massive species show high recovery from bleaching events (Wilkinson 1998, 2000, Sheppard 1999), and it is a dominant component of Indo-Pacific reefs, comprising an average of $30 \%$ of live hard coral cover on our reefs. It is alarming, therefore, that all of the diseases we consistently observed appeared to target this genus, both those which suggest a biotic cause (i.e. a pathogen, such as PUWS) and those considered to be abiotic (i.e. caused by environmental stressors, such as pigmentation response). The potential for significant impacts on reef structure may be quite high, as this prominent genus, massive Porites in particular, is host to multiple diseases. Long-term monitoring is essential to determine what impacts these diseases will have on the future structure and diversity of these reefs. In-depth studies of disease pathogenesis, differential species susceptibility, host defensive capabilities, etiology and causative agents are also urgently needed.

This preliminary survey has documented that IndoPacific reefs are currently impacted by a number of diseases and syndromes. Detailed information about these syndromes is almost non-existent. PUWS is the only disease that has been quantified in Philippine reefs and much about the disease's etiology and pathogenesis is still unknown. As Philippine reefs are among the most impacted in the world, coral diseases pose further threats to these unique systems and a further challenge to reef management.

Acknowledgements. The authors wish to thank the Silliman University Marine Laboratory and the University of the Philippines Marine Science Institute for logistical support during these surveys. Advice from H. Yap, E. Gomez and
A. Uychiaoco regarding sampling sites and their extensive knowledge of the Lingayen Gulf is gratefully acknowledged. J. Ward gave helpful advice on analyzing our diversity data. Comments by $\mathrm{B}$. Willis on the nature of the pigmentation response and White Syndrome described in this paper are also appreciated. C. D. Harvell and the Harvell lab group reviewed this manuscript; their comments have greatly improved it as have comments by 3 anonymous reviewers. Funding was provided by the World Bank through World Fish (ICLARM).

\section{LITERATURE CITED}

Alder J, Braley RD (1988) Mass mortalities of giant clams on the Great Barrier Reef. In: Copland JW, Lucas JS (eds) Giant clams in Asia and the Pacific. Australian Centre for International Agricultural Research, Canberra, p 230-236

Antonius A (1985) Coral diseases in the Indo-Pacific: A first record. PSZN I: Mar Ecol 6(3):197-218

Antonius A (1988) Distribution and dynamics of coral diseases in the Eastern Red Sea. Proc 6th Int Coral Reef Symp 2: 293-299

Antonius A, Lipscomb D (2000) First protozoan coral-killer identified in the Indo-Pacific. Atoll Res Bull 481:1-21

Aronson RB, Precht WF (1997) Stasis, biological disturbance, and community structure of a Holocene coral reef. Paleobiology 23(3):326-346

Aronson RB, Precht WF, MacIntyre IG (1998) Extrinsic control of species replacement on a Holocene reef in Belize: the role of coral disease. Coral Reefs 17:223-230

Azcuna M (2005) Porites pigmentation response: a noninfectious indication of coral stress. BSc thesis, Silliman, University, Philippines

Ben-Haim Y, Zicherman-Keren M, Rosenberg E (2003) Temperature-regulated bleaching and lysis of the coral Pocillopora damicornis by the novel pathogen Vibrio coralliilyticus. Appl Environ Microbiol 69(7):4236-4242

Bruckner A W (2002) Priorities for effective management of coral diseases. NOAA Tech Mem NMFS-OPR-22. Washington, DC

Burke L, Selig E, Spalding M (2002) Reefs at Risk in Southeast Asia. World Resources Institute, Washington, DC

Clark S, Edwards AJ (1995) Coral transplantation as an aid to reef rehabilitation: evaluation of a case study in the Maldive Islands. Coral Reefs 14:201-213

Coles SL (1994) Extensive coral disease outbreak at Fahl Island, Gulf of Oman, Indian Ocean. Coral Reefs 13:242

Garrison VH, Shinn EA, Foreman WT, Griffin DW and 6 others (2003) African and Asian dust: from desert soils to coral reefs. BioScience 53(5):469-480

Gladfelter WB (1982) White-band disease in Acropora palmata: implications for the structure and growth of shallow reefs. Bull Mar Sci 32(2):639-643

Goreau TJ, Cervino JT, Goreau M, Hayes R and 14 others (1998) Rapid spread of diseases in Caribbean coral reefs. Rev Biol Trop 46(Suppl 5):157-171

Harvell CD, Kim K, Burkholder JM, Colwell RR and 9 others (1999) Emerging marine diseases-climate links and anthropogenic factors. Science 285:1505-1510

Harvell CD, Mitchell CE, Ward JR, Altizer S, Dobson AP, Ostfeld RS, Samuel MD (2002) Climate warming and disease risks for terrestrial and marine biota. Science 296:2158-2162

Hughes TP (1994) Catastrophes, phase shifts, and large-scale degradation of a Caribbean coral reef. Science 265: $1547-1551$ 
Jordan-Dahlgren E, Maldonado MA, Rodriguez-Martinez RE (2005) Diseases and partial mortality in Montastraea annularis species complex in reefs with differing environmental conditions (NW Caribbean and Gulf of Mexico). Dis Aquat Org 63:3-12

Kim K, Dobson AP, Gulland FMD, Harvell CD (2003) Diseases and the conservation of marine biodiversity, Chap 9. In: Norse E, Crowder F (eds) Marine conservation biology: The science of maintaining the sea's biodiversity. Island Press, Washington, DC

Kushmaro A, Rosenberg E, Fine M, Ben-Haim Y, Loya Y (1998) Effect of temperature on bleaching of the coral Oculina patagonica by Vibrio AK-1. Mar Ecol Prog Ser 171:131-137

Kuta KG, Richardson LL (2002) Ecological aspects of black band disease in corals: relationships between disease incidence and environmental factors. Coral Reefs 21:393-398

Lafferty KD, Holt RD (2003) How should environmental stress affect the population dynamics of disease? Ecol Lett 6: 654-664

Littler MM, Littler DS (1996) Black band disease in the South Pacific. Coral Reefs 15(1):654-664

Nagelkerken I, Buchan K, Smith GW, Bonair K and 8 others (1997) Widespread disease in Caribbean sea fans: I. Spreading and general characteristics. In: Lessios $\mathrm{H}_{\text {, }}$ MacIntyre IG (eds) Proc 8th Int Coral Reef Symp 1, Smithsonian Tropical Research Institute, Balboa, p 679-682

Petes LE, Harvell CD, Peters EC, Webb MAH, Mullen KM (2003) Pathogens compromise reproduction and induce melanization in Caribbean sea fans. Mar Ecol Prog Ser 264:167-171

Ravindran J, Raghukumar C (2002) Pink Line Syndrome (PLS) in the coral Porites lutea. Coral Reefs 21:252

Raymundo LJ, Maypa AP (2003) Impacts of the 1997-98 ENSO event: responses of the Apo Island Marine Reserve. Philipp Sci 40:164-176

Editorial responsibility: Albert Sparks, Seattle, Washington, USA
Raymundo LJ, Harvell CD, Reynolds T (2003) Porites ulcerative white spot disease: description, prevalence, and host range of a new coral disease affecting Indo-Pacific Reefs. Dis Aquat Org 56:95-104

Richardson LL (1998) Coral diseases: What is really known? Trends Ecol Evol 13:438-443

Ritchie K, Polson SW, Smith GW (2001) Microbial disease causation in marine invertebrates: problems, practices and future prospects. Hydrobiologia 460:131-139

Rosenzweig ML (1995) Species diversity in space and time. Cambridge University Press, Cambridge

Sheppard CRC (1999) Coral decline and weather patterns over 20 years in the Chagos Archipelago, Central Indian Ocean. Ambio 28:472-478

Spalding M, Ravilious C, Green EP (2001) World atlas of coral reefs. University of California Press, Berkeley, CA

Sutherland KR, Porter JW, Torres C (2004) Disease and immunity in Caribbean and Indo-Pacific zooxanthellate corals. Mar Ecol Prog Ser 266:273-302

Udarbe-Walker MJ, Magdaong E (2003) Circulation and hydrographic characteristics of a mariculture area northwest of Lingayen Gulf. Philipp Sci 40:57-72

Veron JEN (2000) Corals of the world. Australian Institute of Marine Science, Townsville

Ward JR, Lafferty KD (2004) The elusive baseline of marine disease: Are diseases in ocean ecosystems increasing? PLoSBiology 2(4):0542-0447

Wallace C (1999) Staghorn corals of the world. CSIRO Publishing, Collingwood

Wilkinson C (ed) (1998) Status of coral reefs of the world: 1998. Australian Institute of Marine Science, Townsville

Wilkinson C (ed) (2000) Status of coral reefs of the world: 2000. Australian Institute of Marine Science, Townsville

Willis BL, Page CA, Dinsdale EA (2004) Coral disease on the great barrier reef, Chap 3. In: Rosenberg E, Loya Y (eds) Coral health and disease. Springer-Verlag, Berlin, p 66-104

Submitted: August 10, 2004; Accepted: December 10, 2004 Proofs received from author(s): April 19, 2005 